\title{
Study of syntrophic anaerobic digestion of volatile fatty acids using enriched cultures at mesophilic conditions
}

\author{
${ }^{1}$ T. Amani; ${ }^{1 *}$ M. Nosrati; ${ }^{1}$ S. M. Mousavi; ${ }^{2}$ R. K. Kermanshahi \\ ${ }^{1}$ Biotechnology Group, Department of Chemical Engineering, Faculty of Engineering, Tarbiat Modarres \\ University, Tehran, Iran \\ ${ }^{2}$ Department of Biology, Faculty of Basic Sciences, Alzahra University, Tehran, Iran
}

Received 30 June 2010; revised 11 September 2010; accepted 1 November 2010; available online 1 December 2010

\begin{abstract}
Volatile fatty acids are the most important intermediates in anaerobic digestion, and their degradations are extremely complicated thermodynamically. In this research, syntrophic anaerobic digestion of volatile fatty acids using enriched acetogenic and methanogenic cultures in a batch reactor at mesophilic conditions was investigated. Interactive effects of key microbiological and operating variables (propionic, butyric and acetic acids, retention time and methanogen to acetogen populations ratio) on the anaerobic degradation of volatile fatty acids were analyzed. Acetogenic and methanogenic anaerobes in the granular sludge from an up-flow anaerobic sludge blanket reactor were enriched at mesophilic conditions within a period of four weeks, separately. Enriched cultures were mixed with known proportions and then used in the bioreactor. Experiments were carried out based on central composite design and analyzed using response surface methodology. Four parameters (final concentrations of propionic, butyric and acetic acids and biogas production) were directly measured as response. Also, the optimum conditions for volatile fatty acid degradation were found to be $937.5 \mathrm{mg} / \mathrm{L}, 3275.5 \mathrm{mg} / \mathrm{L}, 2319.5 \mathrm{mg} / \mathrm{L}, 45 \mathrm{~h}$ and 2.2 proportions for propionic acid, butyric acid, acetic acid, retention time and methanogen to acetogen populations ratio, respectively (corresponding to maximum volatile fatty acid removal efficiencies and biogas production). The results of the verification experiment and the predicted values from the fitted correlations at the optimum conditions were in close agreement at a $95 \%$ confidence interval. The present study provides valuable information about the interrelations of quality and process parameters at different values of microbiological and operating variables.
\end{abstract}

Keywords: Acetogens; Acetogenesis reactions; Methanogens; Methanogenesis reactions

\section{INTRODUCTION}

The anaerobic digestion process is a sequential, complex biochemical process, in which organic compounds are mineralized to biogas (mainly consisting of $\mathrm{CH}_{4}$ and $\mathrm{CO}_{2}$ ) through a series of reactions mediated by several groups of microorganisms. This process, from the view point of microbiology, follows four major steps: hydrolysis, acidogenesis, acetogenesis and methanogenesis (Gerardi, 2003; Metcalf and Eddy, 2004; Bitton, 2005; Nwuche and Ugoji, 2008; Nwuche and Ugoji, 2010). Of the several intermediate stages, acetogenesis and methanogenesis are the most critical steps, in which acetogens (propionate and butyrate degrading bacteria) and methanogens (hydrogenotrophs and aceticlasts) form

ه4 *Corresponding Author Email: mnosrati20@modares.ac.ir Tel.: +9821 82884372; Fax: +98 2182883381 special constructions and are interrelated in what is called a "syntrophic interaction" (Schink and Stams, 2005). Propionate and butyrate are the most important intermediates in the syntrophic reactions, and because of thermodynamic restrictions, their degradations are regarded as the rate limiting steps in the anaerobic digestion. They often accumulate in the anaerobic digester when the process becomes unstable (Kida et al., 1993; de Bok et al., 2004; Wong et al., 2009; Shah et al., 2009; Liu et al., 2010; Hooshyari et al., 2009). The anaerobic oxidations of propionate and butyrate to acetate, $\mathrm{CO}_{2}$ and $\mathrm{H}_{2}$ are highly endergonic $\left(\mathrm{DG}_{\text {Propionate }}^{\circ}=+76.1\right.$ and $\mathrm{DG}_{\text {Butyrate }}^{\circ}=+48.1 \mathrm{~kJ} / \mathrm{mol}$ at 25 ${ }^{\circ} \mathrm{C}$ ) and do not occur naturally and thermodynamically, but these reactions can be accomplished by the syntrophic cooperation of propionate and butyrate- 
oxidizing bacteria and $\mathrm{H}_{2}$ /formate-scavenging partners, which maintain a low $\mathrm{H}_{2}$ partial pressure (Schink and Stams, 2005). The anaerobic conversion of butyrate is not as unfavorable thermodynamically as the anaerobic conversion of propionate, and its accumulation rarely has been reported in the literature.

Studies on the volatile fatty acid (VFA) conversions have been mainly focused on the syntrophic association in the co-cultivation of acetogens with methanogens (Plugge et al., 2002; de Bok et al, 2005; Kosaka et al., 2006; Babel et al., 2007; Tatara et al., 2008). In these studies, the effects of all VFAs, especially propionate, on the activity of acetogens and methanogens have been considered. Several investigators have described the toxic effects of VFAs in the anaerobic digestion process (Pullammanappallil et al., 2001; Han et al., 2005; Gallert and Winter, 2008; Uneo and Tatara, 2008), but the extent of this inhibition has not been properly studied. The main aim of this research was to investigate, analyze and model the syntrophic anaerobic degradation of VFAs and the performance of the enriched acetogenic and methanogenic microorganisms.

It is often necessary to introduce enriched seeding microorganisms to start up anaerobic digesters. The enriched cultures improve the syntrophic reactions. As another contribution in this study, a novel method was applied to enrich the acetogens and methanogens utilizing specific substrates. In the last few years, response surface methodology (RSM) has been applied to analyze, optimize and evaluate interactive effects of independent factors in numerous chemical, biochemical and bioenvironmental processes (Wang et al., 2005; Altaf et al., 2006; Aktap et al., 2006; Zinatizadeh et al., 2006; Ghorbani et al., 2008). Analysis and modeling of anaerobic digestion processes, particularly syntrophic anaerobic degradation of VFAs, using RSM has not yet been reported. In this research, the RSM was used to analyze and model the process with respect to the simultaneous effects of five microbiological and operating variables (propionic acid (HPr), butyric acid $(\mathrm{HBu})$, acetic acid $(\mathrm{HAc})$, methanogen to acetogen populations ratio $(\mathrm{M} / \mathrm{A})$ and retention time $(\mathrm{RT}))$ and four parameters ( $\mathrm{HPr}, \mathrm{HBu}, \mathrm{HAc}$ and biogas production) were assessed as responses. The significant factors and a continuous response surface of the main parameters were developed to provide an optimal region that satisfies the process specifications. This research was carried out in Biopilot Laboratory, Biotechnology Group, Chemical Engineering Department, Tarbiat Modares University during November 2009 to February 2010.

\section{MATERIALS AND METHODS}

\section{Enrichment}

To enrich the acetogens and methanogens, the granular sludge from an up-flow anaerobic sludge blanket (UASB) reactor that is employed in the treatment of dairy wastewater was utilized. The $\mathrm{pH}$ of the granular sludge was 7.4, and the concentrations of volatile suspended solid (VSS) and total suspended solid (TSS) were $67.2 \mathrm{~g} / \mathrm{L}$ and $92.4 \mathrm{~g} / \mathrm{L}$, respectively. To enrich the anaerobes, the minimal medium contained the following: $\mathrm{KH}_{2} \mathrm{PO}_{4}(0.6 \mathrm{~g} / \mathrm{L}), \mathrm{Na}_{2} \mathrm{HPO}_{4}(1.33 \mathrm{~g} / \mathrm{L})$, $\mathrm{NH}_{4} \mathrm{Cl}(0.3 \mathrm{~g} / \mathrm{L}), \mathrm{CaCl}_{2} \cdot \mathrm{H}_{2} \mathrm{O}(0.11 \mathrm{~g} / \mathrm{L}), \mathrm{MgCl}_{2} \cdot 6 \mathrm{H}_{2} \mathrm{O}(0.1$ $\mathrm{g} / \mathrm{L}), \mathrm{NaHCO}_{3}(4.0 \mathrm{~g} / \mathrm{L}), \mathrm{Na}_{2} \mathrm{~S} .9 \mathrm{H}_{2} \mathrm{O}(0.025 \mathrm{~g} / \mathrm{L}), \mathrm{FeCl}_{2}$ $(0.45 \mathrm{~g} / \mathrm{L}), \mathrm{H}_{3} \mathrm{BO}_{4}(0.04 \mathrm{~g} / \mathrm{L}), \mathrm{ZnCl}_{2}(0.032 \mathrm{~g} / \mathrm{L}), \mathrm{CuCl}_{2}$ $(0.0063 \mathrm{~g} / \mathrm{L}), \mathrm{MnCl}_{2}(0.0295 \mathrm{~g} / \mathrm{L}), \mathrm{CoCl}_{2}(0.0305 \mathrm{~g} / \mathrm{L})$, $\mathrm{NiCl}_{2}(0.0062 \mathrm{~g} / \mathrm{L})$, cysteine hydrochloride $(0.05 \mathrm{~g} / \mathrm{L})$ and the yeast extract $(0.05 \mathrm{~g} / \mathrm{L})$. The medium cultures were prepared with distilled water. Before inoculation, $\mathrm{O}_{2}$ was removed from all the culture vessels and media by sparging with the $\mathrm{N}_{2}$ gas for $10 \mathrm{~min}$. The enrichment of propionate- and butyrate-degrading bacteria and methanogens was performed at $37 \pm 1{ }^{\circ} \mathrm{C}$. They were enriched in three Erlenmeyer flasks with working volumes of 1 liter, independently. The carbon sources for enrichment of propionate-, butyrate-degrading bacteria and aceticlasts were $\mathrm{HPr}(3000 \mathrm{mg} / \mathrm{L}), \mathrm{HBu}$ (4000 mg/L) and HAc (5000 mg/L), respectively.

To enrich the anaerobic hydrogenotrophs, hydrogen was produced by the electrolysis of tap water. The schematic representation of the hydrogen generator is shown in Fig. 1. This system consists of a rectifier (maximum voltage: $35 \mathrm{~V}$, and maximum current: 15 A), 2 stainless-steel electrodes (dimensions: $2 \times 300 \times 30 \mathrm{~mm}^{3}$ ) and a vessel containing 8 liters of tap water. Conductivity of water was increased by the addition of 3 to 4 milliliters of concentrated sulfuric acid $(98 \%)$. Under these conditions the maximum electrical current passing through the water was $3 \mathrm{~A}$. $\mathrm{H}_{2}$ gas was produced and collected at the negative electrode, followed by venting it to the vessel containing the granular sludge and HAc as the carbon source. Enrichment of hydrogenotrophs with the $\mathrm{H}_{2}$ gas was performed at a flow rate of $95 \mathrm{~mL} / \mathrm{h}$. The initial 


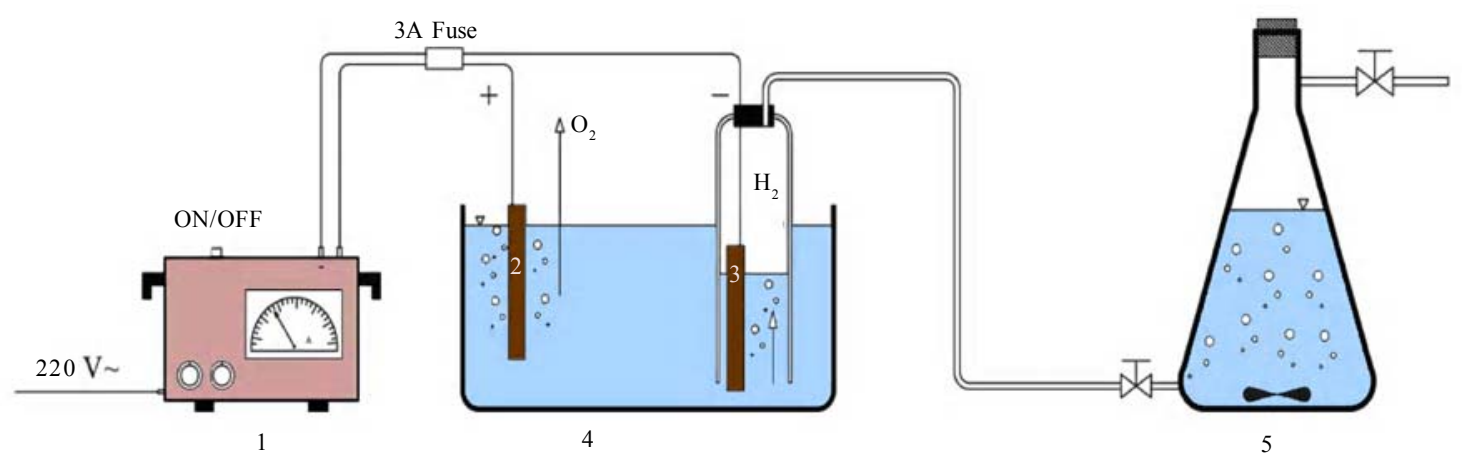

Fig. 1: Schematic representation of hydrogen generator set-up: (1) rectifier, (2) positive electrode, (3) negative electrode, (4) electrolysis vessel and (5) enrichment culture vessel.

$\mathrm{pH}$ was adjusted at $7 \pm 0.1$ with $\mathrm{NaOH}$. The temperature conditions were controlled by using a water bath. The magnetic stirrer was used to mix contents of the vessels during the enrichment process. Mixing was performed daily with the intensity of $50 \mathrm{rpm}$ and duration of $5 \mathrm{~min}$. The initial enrichment cultures were started by adding $200 \mathrm{~mL}$ of the granular sludge to $800 \mathrm{~mL}$ of the minimal medium with the carbon source $(20 \%(\mathrm{v} / \mathrm{v})$ inoculation). Every week, samples of each vessel were drawn, and their $\mathrm{pH}$ and VFA concentrations were assayed. The inoculated culture $(200 \mathrm{~mL})$ was then transferred to the fresh medium $(800 \mathrm{~mL})$. The removal efficiencies of VFAs (more than $95 \%$ removal efficiency) were considered as the criteria to perform the enrichment of the anaerobic microorganisms. After a few transfers, all done according to the defined criteria, the enrichment processes were considered complete and the anaerobic microorganisms continued to remain in the cultures.

\section{Substrates}

The synthetic wastewater, containing pure $\mathrm{HPr}, \mathrm{HBu}$ and HAc (Merck Inc., Germany), as well as tap water with different concentrations (low to high loads), were used as the major carbon sources and electron donors in this study. To supply adequate nitrogen and phosphorus for the microorganisms, chemical oxygen demand (COD):N:P ratio was maintained at 100:4:1. $\mathrm{O}_{2}$ was removed by $\mathrm{N}_{2}$ sparging for $10 \mathrm{~min}$ before feeding to the bioreactor. The $\mathrm{pH}$ of the feed and within the reactor was not regulated throughout the experiment (4.5-5.5). To increase the alkalinity, $\mathrm{NaHCO}_{3}(4 \mathrm{~g} / \mathrm{L})$ was added to the feed.

\section{Batch reactor and operating conditions}

A flow diagram of the experimental set-up is shown in Fig. 2. The batch reactor was a glass cylinder with a diameter of $10 \mathrm{~cm}$ and a height of $15 \mathrm{~cm}$ (working volume $1 \mathrm{~L}$ ). Effluent samples were drawn from the bottom of the reactor using a sampling port. Prior to the experiments, a $200 \mathrm{~mL}(20 \%(\mathrm{v} / \mathrm{v})$ inoculation $)$ mixture of the enriched cultures (methanogens and acetogens) with defined $\mathrm{M} / \mathrm{A}$ was used to seed the batch reactor. For starting up the bioreactor, the ratio of methanogens to acetogens (M/A) was taken as the relative amount of their VSS concentrations. An electrical heating tape (heating capacity: $40 \mathrm{~W} / \mathrm{m}$ ) was attached to the outside surface of the reactor and a temperature probe was connected to the transmitter. The temperature of the reactor was set to the mesophilic $\left(37 \pm 1{ }^{\circ} \mathrm{C}\right)$ condition. To ensure efficient transfer of the intermediates and to release gas bubbles trapped in the medium mixing was performed with an intensity of $50 \mathrm{rpm}$, duration of $5 \mathrm{~min}$ per each $10 \mathrm{~h}$, using a magnetic stirrer. The produced biogas was vented out the top of the bioreactor through a connecting pipe and was collected by the waterdisplacement method. Generally, concentrations of $\mathrm{HPr}, \mathrm{HBu}$ and $\mathrm{HAc}, \mathrm{RT}$, temperature, mixing, $\mathrm{pH}$ and the relative population of syntrophic microorganisms, all affect the anaerobic digestion of the VFAs. To investigate the syntrophic anaerobic digestion of VFAs, concentrations of $\mathrm{HPr}, \mathrm{HBu}$ and $\mathrm{HAc}$, RT and $\mathrm{M} / \mathrm{A}$ were selected as the primary factors affecting the study, and central composite design (CCD) was used to design the experiments. The RSM used in the present study was CCD, which is the most popular 
Syntrophic anaerobic digestion of volatile fatty acids

Table 1: The level of factors in CCD

\begin{tabular}{|c|c|c|c|c|c|}
\hline Factor & Low Axial & Low Factorial & Center & High Factorial & High Axial \\
\hline & $(-\alpha)$ & $(-1)$ & (0) & $(+1)$ & $(+\alpha)$ \\
\hline A: RT (h) & 11 & 25 & 35 & 2.5 & 59 \\
\hline $\begin{array}{l}\text { B: M/A ratio } \\
\text { (g VSS methanogens } / g \text { VSS acetogens) }\end{array}$ & 1.1 & 1.7 & 2.1 & 2150.0 & 3.1 \\
\hline $\mathrm{C}: \mathrm{HPr}$ concentration $(\mathrm{mg} / \mathrm{L})$ & 101 & 937 & 1543.5 & 4980.0 & 2968.0 \\
\hline $\mathrm{D}: \mathrm{HBu}$ concentration $(\mathrm{mg} / \mathrm{L})$ & 0 & 2031.9 & 3506 & 5685.0 & 70011.9 \\
\hline E: HAc concentration $(\mathrm{mg} / \mathrm{L})$ & 0 & 2319.5 & 4002.3 & & 8004.5 \\
\hline
\end{tabular}

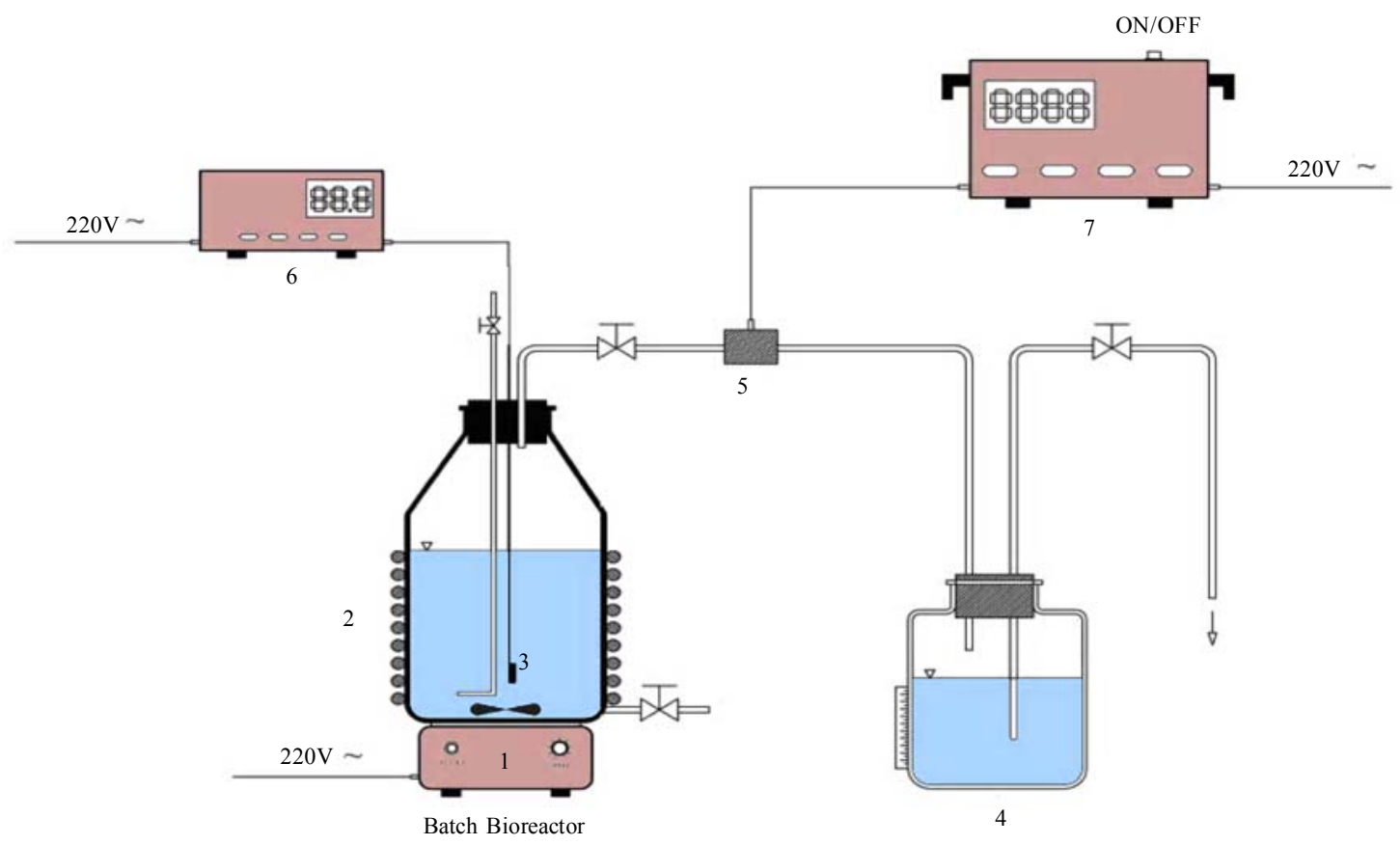

Fig. 2: Schematic flow diagram of experimental set-up: (1) magnetic stirrer, (2) electrical heating tape, (3) temperature probe, (4) biogas collector vessel, (5) methane sensor, (6) temperature controller and (7) methane sensor transmitter.

response surface method (Anderson and Whitcomb, 2000; Myers and Montgomery, 2002; Söteman et al., 2005). The levels of the factors are shown in Table 1. Each factor was varied at five levels, whereas the other parameters were kept constant. Consequently, 47 experiments were conducted; 32 of them organized in a full factorial design, 10 experiments were related to axial points and 5 experiments were done in center points. The remaining five involved repetition of the central idea to get a good estimate of the experimental error. Experiments were designed by Design Expert (DX) Software (State-Ease Inc., version 7.0.0), which is a Windows-compatible software. It provides efficient design of the experiments (DOEs) for identification of the vital factors that affect the process and uses RSM to determine the optimal conditions.

\section{Analytical methods}

Methane concentration in produced biogas was determined with Figaro TGS 2611 methane sensor (made in USA). The sensing element is comprised of a metal oxide semi-conductor layer formed on an alumina substrate of a sensing chip together with an integrated heater. In the presence of a detectable methane, the sensor's conductivity increases depending on the methane concentration. A simple electrical circuit can convert the change in conductivity to an output signal which corresponds to the methane concentration.

The liquid samples were first centrifuged at 10,000 rpm for $15 \mathrm{~min}$, followed by the $\mathrm{HCl}$ acidification, and finally assayed. The VFAs (HAc, $\mathrm{HPr}$ and $\mathrm{HBu}$ ) were quantified using the Agilent gas chromatograph (model 
Int. J. Environ. Sci. Tech., 8 (1), 83-96, Winter 2011

Table 2: The results of enrichment process.

\begin{tabular}{|c|c|c|c|c|c|c|c|c|}
\hline & \multirow{2}{*}{$\begin{array}{c}\text { Time } \\
\text { (Week) }\end{array}$} & \multicolumn{2}{|c|}{ VFA (mg/L) } & \multirow{2}{*}{$\begin{array}{c}\text { VFA } \\
\text { removal } \\
(\%)\end{array}$} & \multicolumn{2}{|c|}{$\mathrm{COD}(\mathrm{mg} / \mathrm{L})$} & \multirow{2}{*}{$\begin{array}{c}\text { COD } \\
\text { Removal } \\
(\%)\end{array}$} & \multirow{2}{*}{$\begin{array}{c}\text { Final } \\
\mathrm{pH}\end{array}$} \\
\hline & & Initial & Final & & Initial & Final & & \\
\hline \multirow{4}{*}{$\begin{array}{r}\text { Pr.-degrading bacteria } \\
\text { (carbon source HPr) }\end{array}$} & $1^{\text {st }}$ Week & 3000.0 & 1882.3 & 37 & 4451.2 & 3069.9 & 30 & 7.4 \\
\hline & $2^{\text {nd }}$ Week & 3000.0 & 576.5 & 81 & 4451.2 & 1104.6 & 75 & 7.9 \\
\hline & $3^{\text {rd }}$ Week & 3000.0 & 110.1 & 96 & 4451.2 & 275.7 & 94 & 7.9 \\
\hline & $4^{\text {th }}$ Week & 3000.0 & 106.3 & 96 & 4451.2 & 265.3 & 94 & 7.9 \\
\hline \multirow{4}{*}{$\begin{array}{c}\text { Bu.-degrading bacteria } \\
\text { (carbon source } \mathrm{HBu} \text { ) }\end{array}$} & $1^{\text {st }}$ Week & 4000.0 & 2478.7 & 38 & 7268.0 & 4846.7 & 33 & 7.7 \\
\hline & $2^{\text {nd }}$ Week & 4000.0 & 525.3 & 87 & 7268.0 & 1047.8 & 86 & 7.9 \\
\hline & $3^{\text {rd }}$ Week & 4000.0 & 75.2 & 98 & 7268.0 & 303.6 & 96 & 8.0 \\
\hline & $4^{\text {th }}$ Week & 4000.0 & 74.2 & 98 & 7268.0 & 297.9 & 96 & 8.0 \\
\hline Methanogens & $1^{\text {st }}$ Week & 5000.0 & 2293.4 & 54 & 5286.6 & 2394.8 & 55 & 7.4 \\
\hline \multirow[t]{3}{*}{ (carbon source HAc) } & $2^{\text {nd }}$ Week & 5000.0 & 785.6 & 84 & 5286.6 & 809.7 & 85 & 7.6 \\
\hline & $3^{\text {rd }}$ Week & 5000.0 & 619.8 & 88 & 5286.6 & 750.7 & 86 & 7.6 \\
\hline & $4^{\text {th }}$ Week & 5000.0 & 196.2 & 96 & 5286.6 & 285.4 & 95 & 7.7 \\
\hline
\end{tabular}

7890), equipped with an auto-injector (7683 B series), a flame ionization detector (FID) $\left(\mathrm{H}_{2}\right.$ flow rate: $35 \mathrm{~mL} /$ $\mathrm{min}$, air flow rate: $350 \mathrm{~mL} / \mathrm{min}$ ) and a Chrompack CpWax $52 \mathrm{CB}$ fused-silica column $(25 \mathrm{~m} \times 0.32 \mathrm{~mm}$ i.d. and $0.2 \mathrm{im}$ film thickness). The injector and detector temperatures were kept constant at $240{ }^{\circ} \mathrm{C}$ and $280^{\circ} \mathrm{C}$, respectively. Helium $(\mathrm{He})$ was used as the carrier gas at a flow rate of $3 \mathrm{~mL} / \mathrm{min}$ and makeup flow rate of $5 \mathrm{~mL} /$ min. The oven temperature was programmed at $40{ }^{\circ} \mathrm{C}$ for $4 \mathrm{~min}$, raised to $180^{\circ} \mathrm{C}$ at $30^{\circ} \mathrm{C} / \mathrm{min}$, and then held at $180{ }^{\circ} \mathrm{C}$ for $1 \mathrm{~min}$. The VSS, TSS and COD were determined according to the standard methods (APHA, 1992). The $\mathrm{pH}$ was measured using the Metrohm 620 pH meter (made in Germany).

\section{RESULTS AND DISCCUTION}

\section{Enrichments}

Concentrations of COD, VFAs ( $\mathrm{HPr}, \mathrm{HBu}$ and $\mathrm{HAc}$ ) and $\mathrm{pH}$, during the enrichment processes were measured at the end of each transfer. The initial and ultimate concentrations of COD, VFAs and $\mathrm{pH}$ in the enrichment cultures of propionate- and butyratedegrading bacteria (acetogens) and methanogens are shown in Table 2. The results of COD and VFA removal efficiencies were in good agreement with each other. Increases of $\mathrm{HPr}, \mathrm{HBu}$ and $\mathrm{HAc}$ removal efficiencies or decreases of their ultimate concentrations were stepwise gradual. These results showed that after four transfers (four weeks) VFA removals were greater than $95 \%$. Thus, according to the defined criteria, it could be concluded that acetogens and methanogens in the granular sludge prevailed in the cultures.

During the enrichment process the initial granules were broken down gradually, and in the end of the fourth week, almost all of the microorganisms were completely dispersed. The reason is that only one VFA was used for the enrichment of each group of microorganisms and the syntrophic reactions were not complete. Therefore, the enriched cultures obtained by the reaction, especially acetogens, were not granular and were fine or dispersed at the end of the enrichment processes. Enriched cultures (with known ratio) were thickened and then used for the syntrophic anaerobic digestion of VFAs in the bioreactor. The concentrations of the propionate-degrading bacteria in the enriched cultures were VSS $=68.4 \mathrm{~g} / \mathrm{L}$ and TSS $=78.2$ $\mathrm{g} / \mathrm{L}$. For butyrate-degrading bacteria, the concentrations were VSS=71.2 $\mathrm{g} / \mathrm{L}$ and $\mathrm{TSS}=81.3 \mathrm{~g} / \mathrm{L}$; and for methanogens, they were VSS $=74.3 \mathrm{~g} / \mathrm{L}$ and TSS $=84.5 \mathrm{~g} /$ L. To verify the performance of each enriched culture against a different feed, the enriched cultures were inoculated with other carbon sources, i.e., HPr was added to the enriched sludge of butyrate-degrading bacteria and to the enriched sludge of methanogens. Moreover, $\mathrm{HBu}$ was added to the enriched sludge of propionatedegrading bacteria. The minimal medium, temperature and $\mathrm{pH}$ were the same as during the enrichment processes, but the incubation time was 10 days. The concentrations of the initial and ultimate COD are shown in Table 3. The results showed that just before 10 days in culture, low COD removal efficiencies of 19, 11 and 21 percent were observed for the propionate-, butyratedegrading bacteria and methanogens, respectively. These results again revealed that the enriched cultures predominantly contained the propionate- and butyratedegrading bacteria, as well as the methanogens.

\section{Statistical analysis}

Forty seven experiments were designed using CCD. The experimental conditions and their responses for the mesophilic anaerobic digestion process are shown 
T. Amani et al.

Table 3: The results of enrichment processes validity

\begin{tabular}{|c|c|c|c|c|}
\hline \multirow[t]{2}{*}{ Enriched Culture } & \multirow[t]{2}{*}{ Carbon Source } & \multicolumn{2}{|c|}{$\mathrm{COD}(\mathrm{mg} / \mathrm{L})$} & \multirow{2}{*}{$\begin{array}{l}\text { COD Removal Efficiency } \\
(\%)\end{array}$} \\
\hline & & Initial & Final & \\
\hline Pr.-degrading bacteria & $\mathrm{HBu}$ & 7268.0 & 5886.1 & 19 \\
\hline Bu.-degrading bacteria & $\mathrm{HPr}$ & 4451.2 & 3961.6 & 11 \\
\hline Methanogens & $\mathrm{HPr}$ & 4451.2 & 3515.4 & 21 \\
\hline
\end{tabular}

Table 4: The experimental plan of VFA digestion and obtained results

\begin{tabular}{|c|c|c|c|c|c|c|c|c|c|}
\hline \multicolumn{4}{|c|}{ Run } & \multicolumn{3}{|c|}{ Factors } & \multicolumn{3}{|c|}{ Responses } \\
\hline & RT (h) & $\begin{array}{c}\mathrm{M} / \mathrm{A} \\
(\mathrm{mg} / \mathrm{L})\end{array}$ & $\begin{array}{c}\mathrm{HPr} \\
(\mathrm{mg} / \mathrm{L})\end{array}$ & $\begin{array}{c}\mathrm{HBu} \\
(\mathrm{mg} / \mathrm{L})\end{array}$ & $\begin{array}{c}\text { HAc } \\
(\mathrm{mg} / \mathrm{L})\end{array}$ & $\begin{array}{c}\mathrm{HPr} \\
(\mathrm{mg} / \mathrm{L})\end{array}$ & $\begin{array}{c}\mathrm{HBu} \\
(\mathrm{mg} / \mathrm{L})\end{array}$ & $\begin{array}{c}\text { HAc } \\
(\mathrm{mg} / \mathrm{L})\end{array}$ & $\begin{array}{c}\text { Biogas } \\
(\mathrm{m} / \mathrm{L})\end{array}$ \\
\hline 1 & 45 & 2.5 & 2150.0 & 4980.0 & 2319.5 & 1557.8 & 3318.4 & 1740.6 & 1486 \\
\hline 2 & 45 & 2.5 & 937.0 & 2031.9 & 2319.5 & 380.9 & 792.9 & 871.4 & 1456 \\
\hline 3 & 45 & 2.5 & 2150.0 & 4980.0 & 5685.0 & 1708.9 & 3761.3 & 3487.2 & 1610 \\
\hline 4 & 45 & 1.7 & 2150.0 & 2031.9 & 2319.5 & 1364.1 & 1163.1 & 1558.2 & 1183 \\
\hline 5 & 25 & 1.7 & 937.0 & 2031.9 & 5685.0 & 680.7 & 1996.8 & 3807.7 & 850 \\
\hline 6 & 25 & 1.7 & 2150.0 & 4980.0 & 5685.0 & 1807.3 & 4302.7 & 4865.1 & 893 \\
\hline 7 & 35 & 2.1 & 1543.5 & 3506.0 & 4002.3 & 912.2 & 1415.4 & 2187.8 & 2060 \\
\hline 8 & 45 & 2.5 & 937.0 & 2031.9 & 5685.0 & 576.2 & 1879.7 & 2158.4 & 1476 \\
\hline 9 & 35 & 1.1 & 1543.5 & 3506.0 & 4002.3 & 1394.1 & 2864.9 & 3213.6 & 794 \\
\hline 10 & 25 & 1.7 & 937.0 & 4980.0 & 5685.0 & 765.4 & 4465.1 & 4343.9 & 875 \\
\hline 11 & 25 & 2.5 & 2150.0 & 2031.9 & 5685.0 & 1405.1 & 1448.5 & 3466.7 & 1435 \\
\hline 12 & 35 & 2.1 & 1543.5 & 3506.0 & 0.0 & 658.8 & 1598.7 & 386.6 & 1375 \\
\hline 13 & 35 & 2.1 & 101.0 & 3506.0 & 4002.3 & 62.4 & 2291.4 & 2070.4 & 1375 \\
\hline 14 & 35 & 2.1 & 1543.5 & 7011.9 & 4002.3 & 1339.3 & 6181.4 & 3921.8 & 645 \\
\hline 15 & 45 & 2.5 & 2150.0 & 2031.9 & 5685.0 & 1278.2 & 1331.3 & 2589.7 & 1756 \\
\hline 16 & 45 & 1.7 & 937.0 & 4980.0 & 2319.5 & 617.1 & 2577.6 & 1378.4 & 1920 \\
\hline 17 & 35 & 2.1 & 1543.5 & 3506.0 & 4002.3 & 923.4 & 1522.3 & 2119.5 & 2055 \\
\hline 19 & 25 & 2.5 & 937.0 & 4980.0 & 5685.0 & 746.9 & 4024.9 & 3382.5 & 1458 \\
\hline 20 & 25 & 1.7 & 2150.0 & 4980.0 & 2319.5 & 1741.7 & 3779.2 & 2288.4 & 995 \\
\hline 21 & 25 & 1.7 & 2150.0 & 2031.9 & 5685.0 & 1436.5 & 1580.1 & 3824.4 & 1286 \\
\hline 22 & 45 & 1.7 & 2150.0 & 4980.0 & 5685.0 & 1738.3 & 3881.9 & 4698.1 & 1305 \\
\hline 23 & 35 & 3.1 & 1543.5 & 3506.0 & 4002.3 & 1296.3 & 2845.1 & 2878.6 & 904 \\
\hline 24 & 45 & 1.7 & 937.0 & 4980.0 & 5685.0 & 680.8 & 3696.1 & 3820.8 & 1535 \\
\hline 25 & 35 & 2.1 & 1543.5 & 0.0 & 4002.3 & 456.7 & 0.0 & 2176.8 & 1150 \\
\hline 26 & 35 & 2.1 & 1543.5 & 3506.0 & 8004.5 & 1049.4 & 1815.4 & 7168.9 & 1545 \\
\hline 27 & 45 & 1.7 & 2150.0 & 4980.0 & 2319.5 & 1587.9 & 3401.2 & 2148.5 & 1276 \\
\hline 28 & 25 & 1.7 & 2150.0 & 2031.9 & 2319.5 & 1498.1 & 1304.1 & 1757.6 & 945 \\
\hline 29 & 25 & 2.5 & 2150.0 & 4980.0 & 2319.5 & 1715.5 & 3646.7 & 2232.3 & 1045 \\
\hline 30 & 35 & 2.1 & 1543.5 & 3506.0 & 4002.3 & 895.6 & 1378.3 & 2208.7 & 2145 \\
\hline 31 & 45 & 1.7 & 2150.0 & 2031.9 & 5685.0 & 1284.4 & 1377.6 & 3498.4 & 1565 \\
\hline 32 & 25 & 2.5 & 937.0 & 2031.9 & 5685.0 & 638.3 & 2112.1 & 2598.2 & 1190 \\
\hline 33 & 25 & 2.5 & 2150.0 & 2031.9 & 2319.5 & 1190.1 & 1288.0 & 1166.5 & 1295 \\
\hline 34 & 45 & 2.5 & 937.0 & 4980.0 & 2319.5 & 607.4 & 2504.5 & 1077.8 & 1985 \\
\hline 35 & 59 & 2.1 & 1543.5 & 3506.0 & 4002.3 & 821.6 & 1278.7 & 1857.4 & 2435 \\
\hline 36 & 45 & 2.5 & 2150.0 & 2031.9 & 2319.5 & 1092.3 & 1033.6 & 1045.9 & 1544 \\
\hline 37 & 35 & 2.1 & 1543.5 & 3506.0 & 4002.3 & 906.3 & 1389.1 & 2232.8 & 2115 \\
\hline 38 & 45 & 2.5 & 937.0 & 4980.0 & 5685.0 & 667.2 & 3622.5 & 2764.1 & 1912 \\
\hline 39 & 45 & 1.7 & 937.0 & 2031.9 & 5685.0 & 593.8 & 1906.7 & 2960.1 & 1193 \\
\hline 40 & 25 & 1.7 & 937.0 & 2031.9 & 2319.5 & 471.6 & 1114.1 & 1435.3 & 1085 \\
\hline 41 & 35 & 2.1 & 2986.0 & 3506.0 & 4002.3 & 2286.7 & 2434.3 & 3682.5 & 1125 \\
\hline 42 & 25 & 2.5 & 937.0 & 4980.0 & 2319.5 & 651.9 & 2844.3 & 1234.9 & 1713 \\
\hline 43 & 11 & 2.1 & 1543.5 & 3506.0 & 4002.3 & 1084.6 & 3085.6 & 3063.4 & 860 \\
\hline 44 & 25 & 2.5 & 2150.0 & 4980.0 & 5685.0 & 1891.8 & 4105.0 & 3961.4 & 1230 \\
\hline 45 & 25 & 1.7 & 937.0 & 4980.0 & 2319.5 & 774.4 & 3098.1 & 1447.8 & 1513 \\
\hline 46 & 45 & 1.7 & 937.0 & 2031.9 & 2319.5 & 424.1 & 914.3 & 1285.0 & 1230 \\
\hline 47 & 35 & 2.1 & 1543.5 & 3506.0 & 4002.3 & 901.1 & 1446.6 & 2123.6 & 2175 \\
\hline
\end{tabular}


in Table 4. Because four responses were investigated in this study, the results were inserted into DX-7 software and were fitted to quadratic correlations and then, correlations were found to be adequate for the prediction of the response variables. The analysis of variance (ANOVA) results for the responses have been summarized in Table 5. The relatively high values of $\mathrm{R}^{2}$ indicate that the quadratic equations for output HPr, $\mathrm{HBu}, \mathrm{HAc}$ and biogas production are well capable of representing the system under the given experimental domain. As can be observed in Table 5, there is very little difference between $\mathrm{R}^{2}$ and adjusted- $\mathrm{R}^{2}$, which shows there is a good chance that important terms are included and considered in the correlations.

The correlation terms in the equations are those essential terms that remained after elimination of insignificant variables and their interactions. As seen in the table, the fitted correlations are significant with a $95 \%$ confidence interval ( $p$-value $<0.0001$ ) for the four responses. The correlation adequacy was tested through lack-of-fit F-tests (Montgomery, 1991). The lack-of-fit F-statistic was not statistically significant because the p-values were greater than 0.05 . Adequate precision is a measure of the range of predicted response relative to its associated error or, in other words, a signal-to-noise ratio. Its desired value is 4 or more (Mason et al., 2003). The values were found to be acceptable for the three correlations; see the adequate precision column in Table 5 with values that are much more than 4. Simultaneously, low values of the coefficient of variation $(\mathrm{CV})$ for the responses indicated good accuracy and dependability of the experiments.

\section{Effects of M/A and RT on VFA removal}

Anaerobic digestion of $\mathrm{HPr}$ and $\mathrm{HBu}$ are highly endergonic and do not occur naturally (from the view point of thermodynamic principles) in anaerobic digesters (Schink and Stams, 2005). Small populations of methanogens are not able to metabolize the hydrogen and HAc produced by the acetogens. Increasing the methanogenic population could be used as a method to promote these reactions efficiently (Schmidt and Ahring, 1995).

In this study, to investigate the effect of the methanogenic population on the anaerobic conversion of VFAs, the ratio was adjusted within a range of 1 to 3 . Fig. 3 shows the effect of M/A on VFA removals. When $\mathrm{M} / \mathrm{A}$ was increased from 1.1 to 2.1 (when $\mathrm{HPr}=1543.5$ $\mathrm{mg} / \mathrm{L}, \mathrm{HBu}=2000.8 \mathrm{mg} / \mathrm{L}, \mathrm{HAc}=2499.9 \mathrm{mg} / \mathrm{L}$ and $\mathrm{RT}=$
$35 \mathrm{~h}$ ), the removal efficiencies of $\mathrm{HPr}, \mathrm{HBu}$ and $\mathrm{HAc}$ increased from 10,18 and 20 to 41,59 and $46 \%$, respectively. However, when $\mathrm{M} / \mathrm{A}=3.1$, the removal rates decreased. This showed that in very high $\mathrm{M} / \mathrm{A}$ ranges, the acetogens (propionate- and butyrateoxidizing bacteria) were not sufficient to degrade high concentrations of $\mathrm{HPr}$ and $\mathrm{HBu}$. In this condition, high levels of $\mathrm{HPr}$ and $\mathrm{HBu}$ inhibited the acetogenic reactions and suppressed the growth of acetogens; consequently, their degradations slowed down. As seen in Fig. 3, higher M/A also caused HAc removal to decrease; this could be attributed to inhibition of the growth of the methanogenic population in the presence of high levels of HAc and reduced $\mathrm{pH}$. Accordingly, in the high $\mathrm{M} / \mathrm{A}$ ranges the activities of all anaerobes dropped off significantly.

The RT had a positive effect on VFA removal: with increasing RT, anaerobic microorganisms adapted to low $\mathrm{pH}$ and removal efficiencies improved. Fig. 4 illustrates the effects of RT and M/A on anaerobic conversion of HPr. From the fitted correlations in Table 5 , it can be concluded that the coefficient of RT is more significant than the $\mathrm{M} / \mathrm{A}$ coefficient for the final concentrations of $\mathrm{HPr}$ and $\mathrm{HBu}$. The interaction of RT and $\mathrm{M} / \mathrm{A}$ is not very significant because the coefficient of the interaction term of the correlations is small.

\section{Effects of VFAs on HPr conversion}

Anaerobic oxidation of HPr is inhibited by VFAs; the extent of this inhibition is dependent on the VFA concentrations and the $\mathrm{pH}$ (Siegert and Banks, 2005).

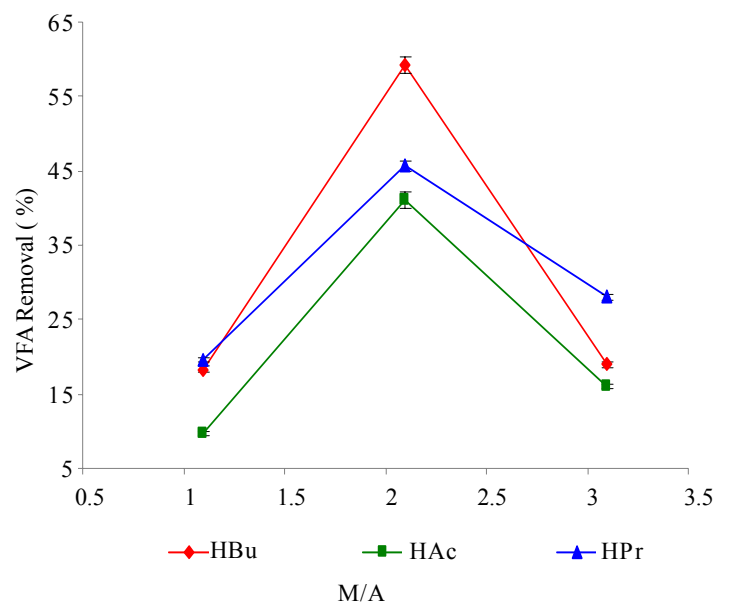

Fig. 3: Effects of M/A on anaerobic conversion of VFAs at constant RT 
Table 5: ANOVA results for the equations of the DX-7 for studied responses

\begin{tabular}{|c|c|c|c|c|c|c|c|c|}
\hline Response & Correlations with significant terms & P-value & $\mathrm{R}^{2}$ & Adj. $R^{2}$ & SD & $\begin{array}{l}\text { Adequate } \\
\text { Precision }\end{array}$ & $\mathrm{CV}$ & Press \\
\hline $\mathrm{HPr}$ & $\begin{array}{l}914.64-53.22 \mathrm{~A}-26.93 \mathrm{~B}+459.16 \mathrm{C}+152.87 \mathrm{D} \\
+63.03 \mathrm{E}-14.65 \mathrm{AC}+18.84 \mathrm{BD}+24.53 \mathrm{BE}+58.71 \mathrm{CD} \\
+11.46 \mathrm{~A}^{2}+80.77 \mathrm{~B}^{2}+50.60 \mathrm{C}\end{array}$ & $<0.0001$ & 0.9912 & 0.9844 & 61.55 & 53.08 & 5.91 & 3708000 \\
\hline $\mathrm{HBu}$ & $\begin{array}{l}1461.76-211.00 \mathrm{~A}-46.11 \mathrm{~B}+60.44 \mathrm{C}+1144.99 \mathrm{D} \\
+284.73 \mathrm{E}+18.80 \mathrm{AB}+14.69 \mathrm{AC}-67.60 \mathrm{AD}-24.95 \mathrm{BD} \\
+139.01 \mathrm{CD}-190.91 \mathrm{CE}+48.80 \mathrm{DE}+148.49 \mathrm{~A}^{2} \\
+267.43 \mathrm{~B}^{2}+180.43 \mathrm{C}^{2}+309.10 \mathrm{D}^{2}+64.50 \mathrm{E}^{2}\end{array}$ & $<0.0001$ & 0.9722 & 0.9509 & 280.32 & 29.07 & 11.90 & 9382000 \\
\hline HAc & $\begin{array}{l}2083.76-203.48 \mathrm{~A}-252.16 \mathrm{~B}+285.86 \mathrm{C}+318.23 \mathrm{D} \\
+1119.14 \mathrm{E}-34.37 \mathrm{AB}+11.05 \mathrm{AC}+20.74 \mathrm{AD}-81.28 \mathrm{AE} \\
-146.74 \mathrm{BE}-106.10 \mathrm{CD}+17.59 \mathrm{CE}+100.18 \mathrm{DE} \\
+109.08 \mathrm{~B}^{2}+79.09 \mathrm{C}^{2}+109.65 \mathrm{D}^{2}+238.42 \mathrm{E}^{2}\end{array}$ & $<0.0001$ & 0.9437 & 0.9004 & 405.38 & 19.65 & 15.69 & 19150000 \\
\hline Biogas & $\begin{array}{l}2117.55+209.52 \mathrm{~A}+103.86 \mathrm{~B}-56.14 \mathrm{C}+17.68 \mathrm{D} \\
+40.16 \mathrm{AD}+29.41 \mathrm{AE}+27.91 \mathrm{BE}-134.53 \mathrm{CD} \\
+94.34 \mathrm{CE}-57.28 \mathrm{DE}-78.02 \mathrm{~A}^{2}-219.17 \mathrm{~B}^{2}-219.17 \mathrm{~B}^{2} \\
-148.28 \mathrm{C}^{2}-210.60 \mathrm{D}^{2}-111.16 \mathrm{E}^{2}\end{array}$ & $<0.0001$ & 0.9116 & 0.8435 & 166.59 & 13.86 & 11.81 & 3189000 \\
\hline
\end{tabular}

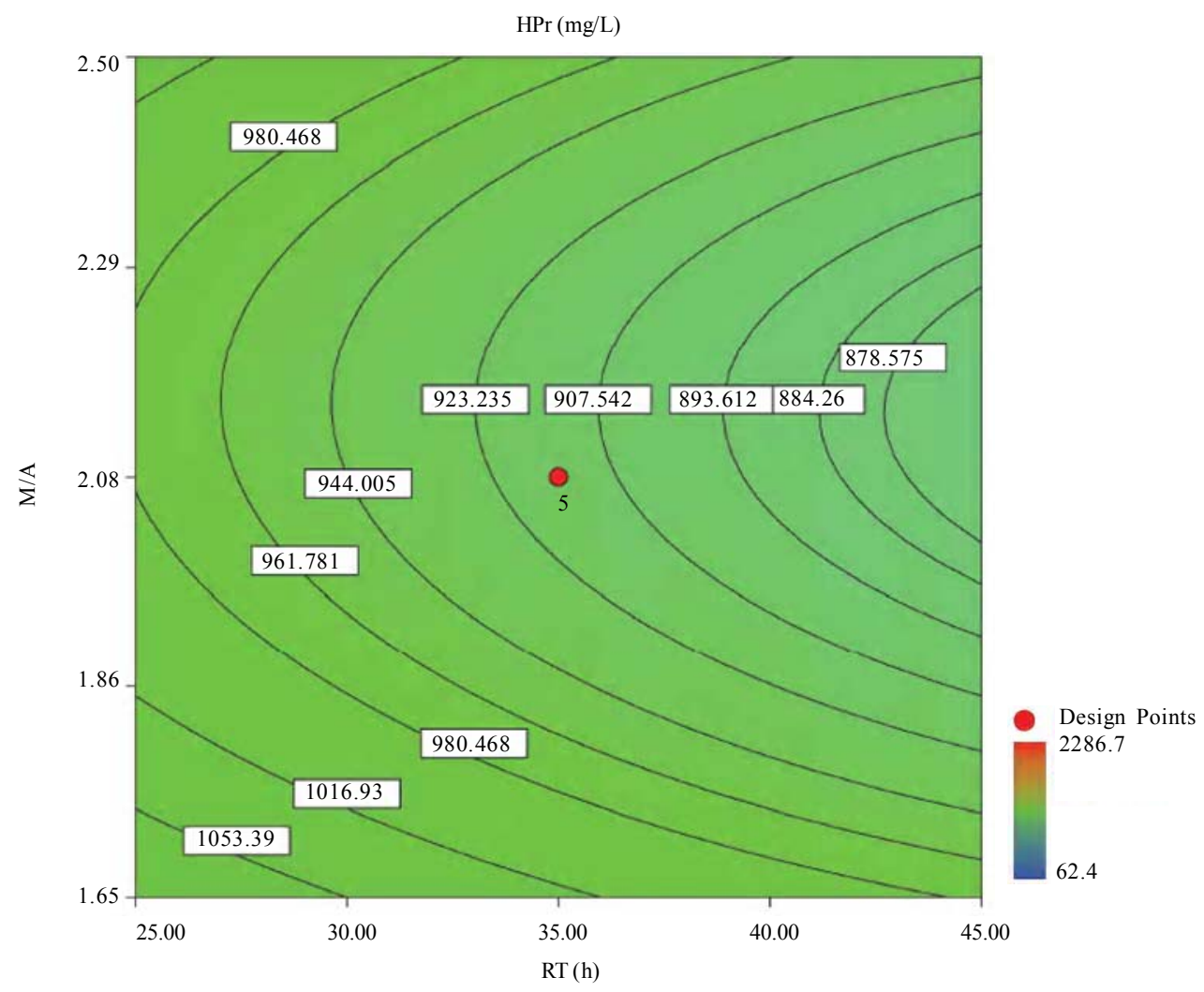

Fig. 4: Effects of RT and M/A on anaerobic conversion of HPr in contour plot

Methanogens are extremely sensitive to $\mathrm{pH}$, with optima between 6.8 and 7.4 (Turovskiy and Mathai, 2006), but acetogenic microorganisms are somewhat less sensitive and can function in a wider range of $\mathrm{pH}$. Generally, the presence of VFAs leads to a drop in $\mathrm{pH}$ in a digester, and their toxicities are steeper when the pH is below 7 (Hwang et al., 2004). Because acetogenic degradation of $\mathrm{HPr}$ and $\mathrm{HBu}$ are extremely endergonic, their anaerobic degradations are repressed thermodynamically. Also, degradation of $\mathrm{HPr}$ and $\mathrm{HBu}$ is inhibited via a $\mathrm{pH}$ drop in the digester. On the other hand, methanogenic conversion of HAc is exergonic; thus it could be expected that its inhibitory effect is due to the $\mathrm{pH}$ drop, which reduces the growth of 


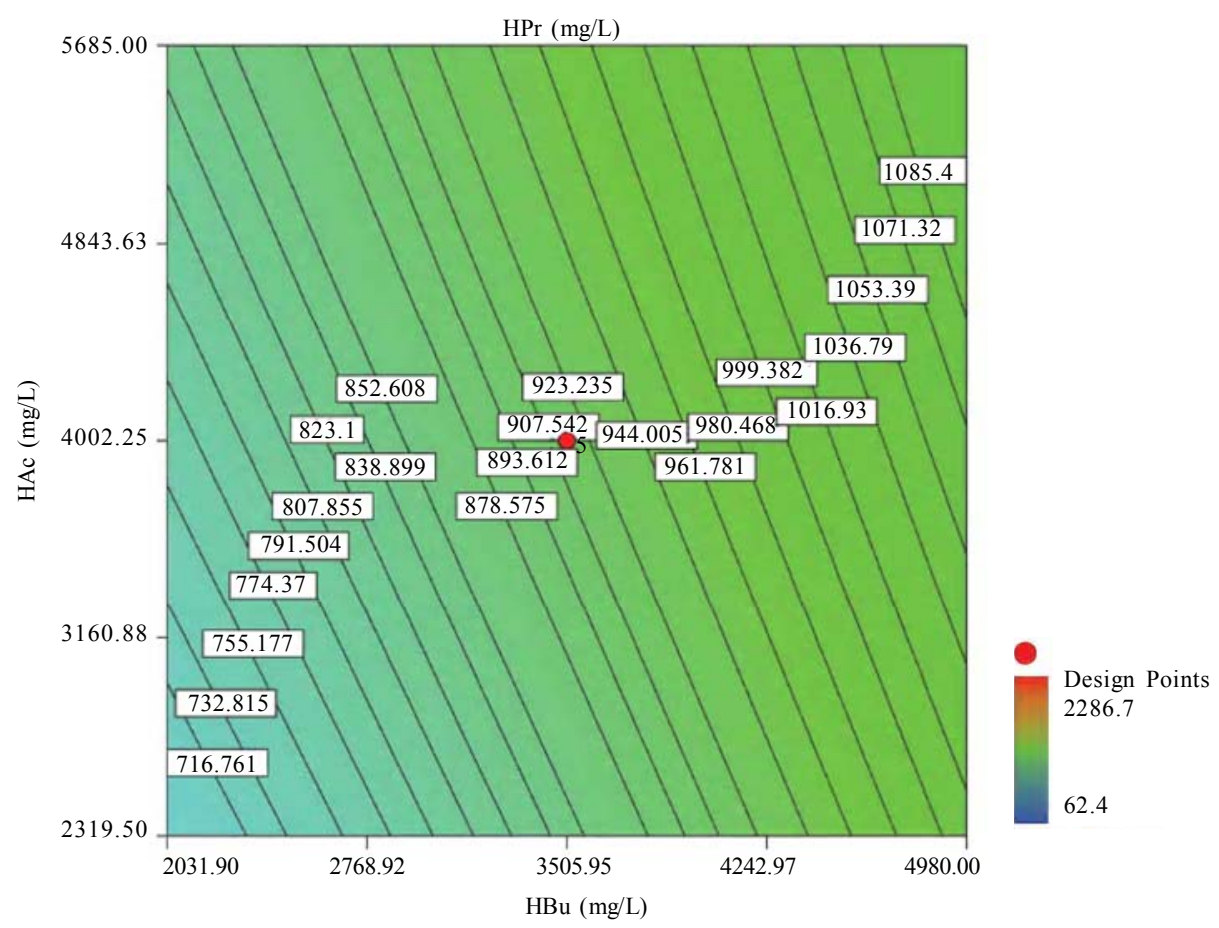

Fig. 5: Effects of HBu and HAc on HPr removal in contour plot

methanogens. In fact, methanogenic oxidation of HAc stimulates HPr degradation thermodynamically. Fig. 5 shows the effects of $\mathrm{HBu}$ and HAc on anaerobic oxidation of HPr. As seen, when concentrations of $\mathrm{HBu}$ and HAc were increased, the HPr removal decreased. The maximum conversion of HPr was obtained when $\mathrm{HBu}$ and $\mathrm{HAc}$ were diminished. Data from the experiments in Table 4 confirmed these results. Furthermore, because the mechanisms of $\mathrm{HBu}$ and HAc inhibition are rather different, their observed inhibitory effects on HPr removal were dissimilar. The coefficient of the HBu term (153) in the fitted correlation in Table 5 was, as expected, greater than that of HAc term (63). Since HAc accumulated when there were high levels of $\mathrm{M} / \mathrm{A}$, the relative inhibitory effects of $\mathrm{HBu}$ and $\mathrm{HAc}$ were not strongly dependent on $\mathrm{M} / \mathrm{A}$; therefore, it seemed that the level of HAc inhibition with higher M/ A was apparently only a little less than HBu. HPr had the largest inhibitory effect on the HPr removal; on the other hand, its coefficient in the fitted correlation (459) is much higher than that for $\mathrm{HBu}$ and HAc.

\section{Effects of VFAs on HBu conversion}

Although anaerobic oxidation of $\mathrm{HBu}$ is not as thermodynamically unfavorable as conversion of $\mathrm{HPr}$, the inhibition pattern of VFAs on anaerobic conversion of $\mathrm{HBu}$ is similar to HPr inhibition. Both HPr and HAc decrease the $\mathrm{pH}$ of the reactor; thus, they can inhibit the growth of acetogenic and methanogenic microorganisms. Thermodynamically HPr hinders, whereas HAc enhances, the anaerobic conversion of $\mathrm{HBu}$. Accordingly, it could be expected that the inhibitory effect of $\mathrm{HPr}$ on $\mathrm{HBu}$ degradation is much higher than the inhibitory effect of HAc. The effects of HPr and HAc on HBu oxidation is shown in Fig. 6.

The results revealed that, in spite of what it would be understood apparently from the above, the inhibitory effect of HAc was greater than that of HPr. The coefficients of their individual terms $(60,285$ for HPr and HAc, respectively) in the fitted correlation confirmed this observation. The main reason could be the effect of $\mathrm{HAc}$ on $\mathrm{pH}$ reduction in the digester, which seriously hindered the growth of anaerobes. Another reason could be attributed to the spatial position or juxtaposition of the syntrophic acetogenic and methanogenic microorganisms (suspended growth). In the syntrophic cultures, diffusion of dissolved intermediates $\left(\mathrm{H}_{2} /\right.$ formate and HAc) from the acetogens (as producers) to the methanogens (as consumers) is the main mechanism; therefore, close microbial proximity plays an important role in this phenomenon. The relative spatial location and mobility of different syntrophic organisms in the 
T. Amani et al.

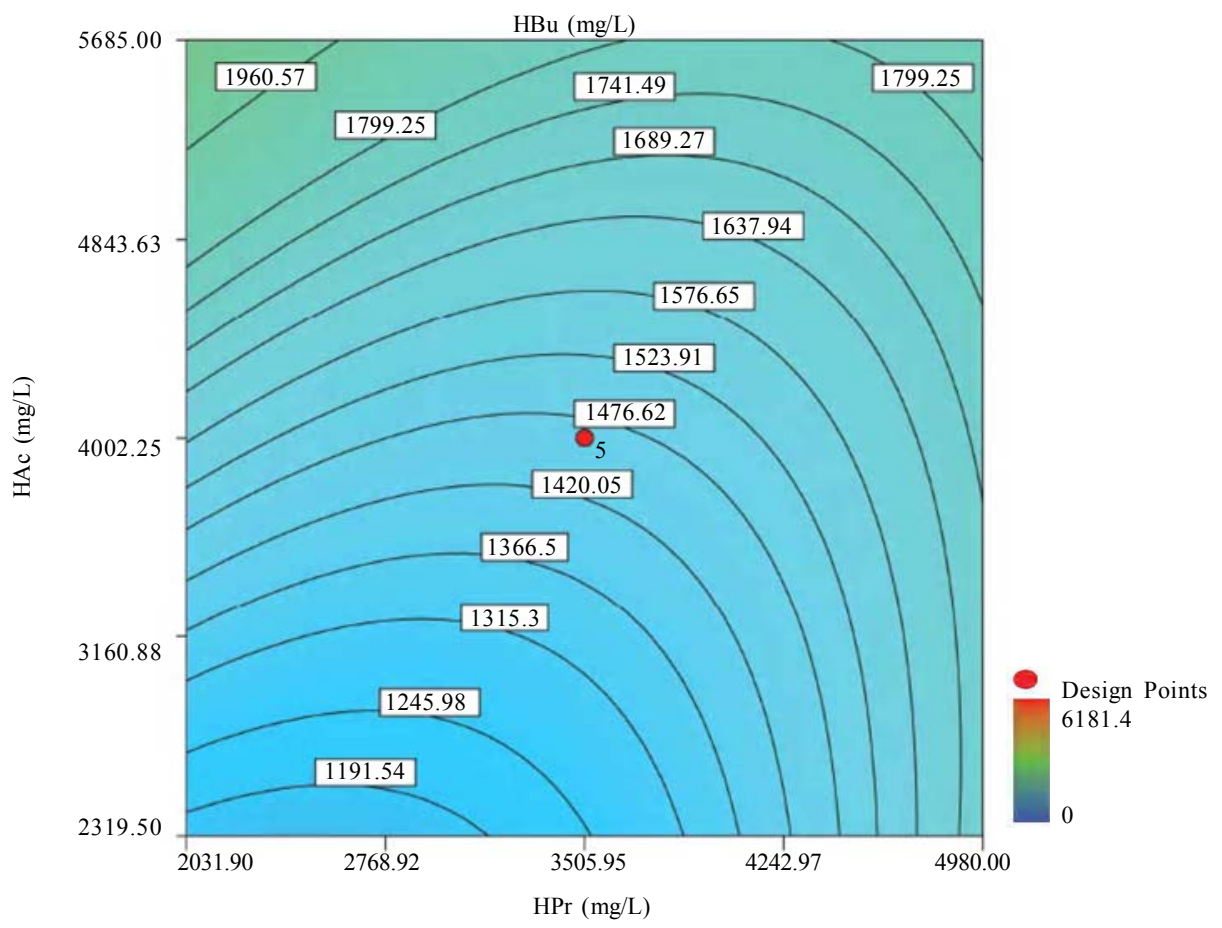

Fig. 6: Effects of HAc and HPr on HBu removal in contour plot

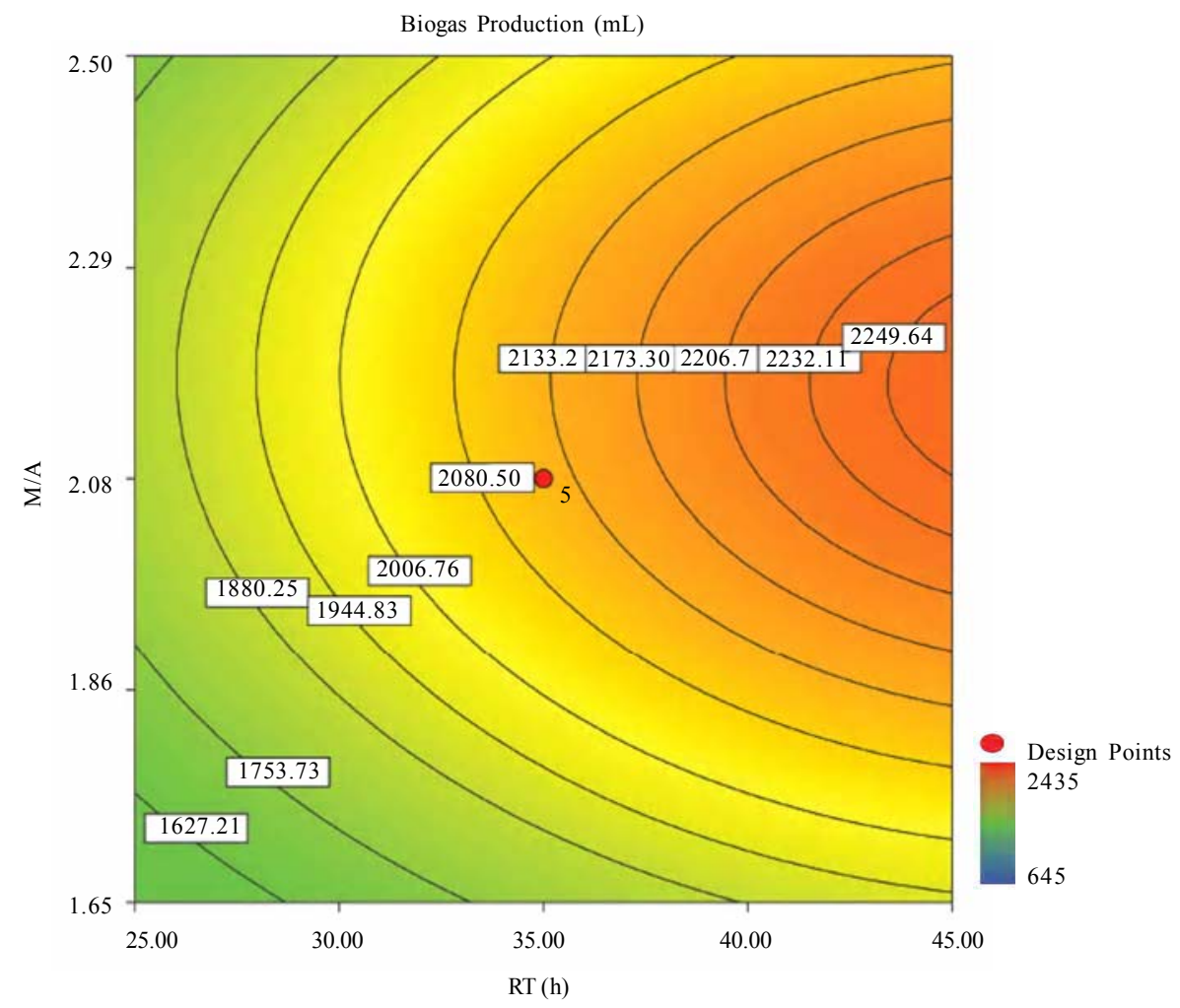

Fig. 7: Effects of RT and M/A on biogas production in contour plot 
bioreactor may play a significant role in controlling the inhibitory effect of HPr and HAc on HBu degradation. Consequently, the movement of butyrate-degrading bacteria probably was inadequate for trouble-free diffusion of intermediates. Similar to HPr, HBu itself had the largest inhibitory effect on $\mathrm{HBu}$ removal, because its coefficient in the fitted correlation (1145) is much higher than that for HPr or HAc.

\section{Biogas production from VFAs}

In this study, all variables directly or indirectly affected biogas production in the syntrophic anaerobic digestion of VFAs, and the extents of the influences were dependent on their levels and interrelated interactions. Fig. 7 shows the effects of RT and M/A on the biogas production. Increasing $\mathrm{M} / \mathrm{A}$ enhanced the methanogenic populations; therefore, the rate of hydrogen consumption was increased, which led to an increase in the biogas production. With higher levels of $\mathrm{M} / \mathrm{A}$, the rate of hydrogen production from acetogenesis reactions (because of the reduction of acetogens) was decreased, and consequently biogas production was reduced critically. Thus, there was an optimum M/A for the biogas production, as seen in Fig. 7. The RT had a positive effect on the biogas production; RT and biogas production increased simultaneously. However, in very high RT ranges, the rate of biogas production was decreased and seemed to even stop. The fitted correlation in Table 5 for the biogas production shows that the effect of RT on biogas production was much greater than the effect of $\mathrm{M} / \mathrm{A}$, but RT/biogas production interaction was not an important term in the correlation.

Fig. 8 illustrates the effects of $\mathrm{HPr}$ and $\mathrm{HBu}$ on the biogas production. $\mathrm{HPr}$ and $\mathrm{HBu}$ to some extent enhanced the biogas production, but in their higher levels, they strongly inhibited the growth of anaerobes, which led to reduction in biogas production. As a result, there were optimum amounts of $\mathrm{HPr}$ and $\mathrm{HBu}$ for the biogas production. The presence of VFAs in the anaerobic digester leads to a reduction in $\mathrm{pH}$ and an inhibition of growth in anaerobes, especially methanogens (Turovskiy and Mathai, 2006). The methanogenesis at low $\mathrm{pH}$ is attributed to the activity of hydrogen-utilizing methanogens that are likely more tolerant to the acidic conditions than the other methanogens (Kim et al., 2004). Because methanogenic activity is decreased in the low levels of $\mathrm{pH}$, the methane yield is decreased significantly. Fig. 9 shows methane content versus final $\mathrm{pH}$ in the anaerobic digestion of VFAs. Although the $\mathrm{pH}$ in the digester was increasing during anaerobic digestion of VFAs, because of the

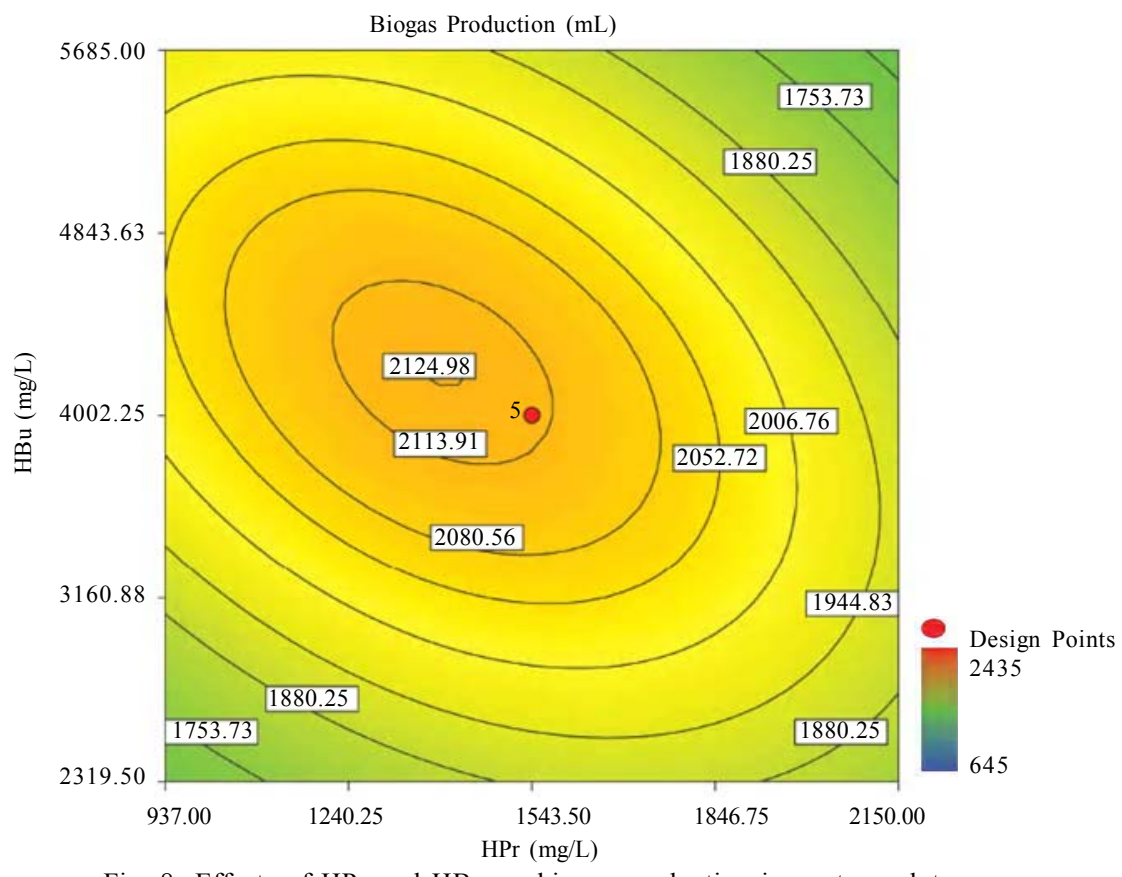

Fig. 8: Effects of $\mathrm{HPr}$ and $\mathrm{HBu}$ on biogas production in contour plot 


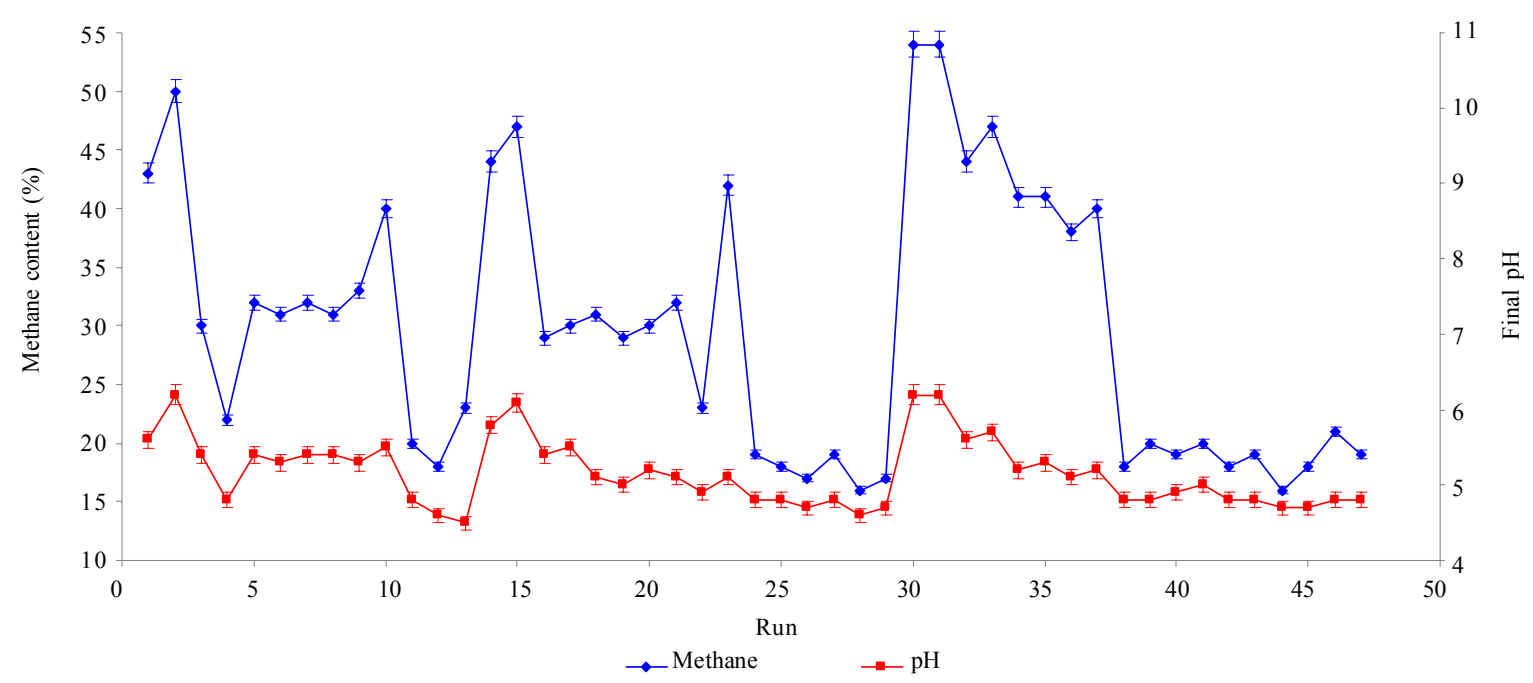

Fig. 9: Final pH vs. methane content for the anaerobic digestion of VFAs.

Table 6: Verification experiment at the optimum conditions

\begin{tabular}{lccrrr}
\hline Responses & Target & Correlation Predicted & Confirmation Experiment & \multicolumn{2}{c}{ Confidence Interval (95\%) } \\
\hline & & & 436.8 & Low & High \\
$\mathrm{HPr}(\mathrm{mg} / \mathrm{L})$ & Minimize & 383.7 & 1196.4 & 699.8 & 444.2 \\
$\mathrm{HBu}(\mathrm{mg} / \mathrm{L})$ & Minimize & 975.3 & 863.2 & 445.2 & 1250.7 \\
$\mathrm{HAc}(\mathrm{mg} / \mathrm{L})$ & Minimize & 843.5 & 1954 & 1913.8 & 1241.9 \\
Biogas $(\mathrm{mL})$ & Minimize & 2077 & 2241 \\
\hline
\end{tabular}

high activity of enriched cultures, the methane content of the biogas was still low.

\section{Maximum VFA removal and biogas production}

According to the main objectives of this experiment (maximum VFA removals and biogas production), the optimum conditions were obtained to be HPr $=937.1$ $\mathrm{mg} / \mathrm{L}, \mathrm{HBu}=3275.5 \mathrm{mg} / \mathrm{L}, \mathrm{HAc}=2319.5 \mathrm{mg} / \mathrm{L}, \mathrm{RT}=45$ $\mathrm{h}$ and $\mathrm{M} / \mathrm{A}=2.2$. To check the accuracy of the fitted correlations of the optimum conditions at the $95 \%$ confidence interval, the batch bioreactor was operated to compare actual responses with predicted responses. Table 6 presents the results of experiments conducted at optimum conditions. The accuracy of the optimum conditions from DOE experiments was checked that the experimental finding was in close agreement with correlation predictions.

\section{CONCLUSION}

Syntrophic anaerobic digestion of VFAs using enriched acetogenic and methanogenic cultures in a batch bioreactor at mesophilic conditions was investigated in this study. Several optimum conditions can be considered, but the main aim of this research was to maximize VFA removal that their anaerobic digestion at high concentrations thermodynamically is intricate or even impossible. The concentrations of $\mathrm{HPr}, \mathrm{HBu}, \mathrm{HAc}, \mathrm{M} / \mathrm{A}$ and $\mathrm{RT}$ were selected as the control factors, and $\mathrm{HPr}, \mathrm{HBu}, \mathrm{HAc}$ and biogas production were the main responses. Analysis of the experimental results using RSM revealed the interrelated interactions of the parameters. RT and M/ A had positive effects on VFA removal; however, performance of the process at very high $\mathrm{M} / \mathrm{A}$ drastically decreased. In the high $\mathrm{M} / \mathrm{A}$ regions, the number of acetogenic bacteria was not sufficient to oxidize HPr and $\mathrm{HBu}$ effectively. The influence of RT on VFA removal and biogas production was more significant than $\mathrm{M} / \mathrm{A}$. $\mathrm{HPr}$ and $\mathrm{HBu}$ inhibited syntrophic oxidation of VFAs thermodynamically as well as via a $\mathrm{pH}$ drop. The effect of $\mathrm{HBu}$ on VFA removal was more significant, which might be due to spatial 
proximity or relative positions of suspended syntrophic organisms in the batch bioreactor. According to the fitted correlations, HPr was the most important parameter because it influenced all the responses and reduced the performance of the process. HAc stimulated VFA removal thermodynamically, but its inhibitory effect due to the $\mathrm{pH}$ drop was significant. Although syntrophic microorganisms, especially methanogens, are very sensitive to low $\mathrm{pH}$, acetogenesis and methanogenesis occurred efficiently in this research work, and the enriched cultures did not lose their activity even at very low $\mathrm{pH}$. Also, $\mathrm{pH}$ was increased during all of the experiments in the anaerobic digestion process. The maximum VFA removals and biogas production occurred when $\mathrm{HPr}=937.1 \mathrm{mg} / \mathrm{L}, \mathrm{HBu}=3275.5 \mathrm{mg} / \mathrm{L}, \mathrm{HAc}=2319.5 \mathrm{mg} / \mathrm{L}$, $\mathrm{RT}=45 \mathrm{~h}$ and $\mathrm{M} / \mathrm{A}=2.2$.

Syntrophic studies may be more accurate when ratios of M/A become more accurate. This may be achieved by obtaining optimum ratios of propionate-degrading bacteria to butyrate-degrading bacteria in the acetogenic microorganisms bulk.

\section{REFERENCES}

Aktap, N.; Boyacý, Ý.H.; Mutlu, M.; Tanyolaç, A., (2006). Optimization of lactose utilization in deproteinated whey by Kluyveromyces marxianus using response surface methodology (RSM). Bioresource. Tech., 97, 2252-2259 (8 pages).

Altaf, M.D.; Naveena, B. J.; Venkatshvar, M.; Kumar, E.V.; Reddy, G., (2006). Single step fermentation of starch to 1(+) lactic acid by lactobacillus amylophilus CV6 in SSF using inexpensive nitrogen sources to replace peptone and yeast extract-optimization by (RSM). Proc. Biochem., 41, 465-472 (8 pages).

Anderson, M. J.; Whitcomb, P. J., (2000). DOE simplified: Practical tools for effective experimentation. Productivity, Inc. Portland, Oregon.

APHA., (1992). Standard methods for the examination of water and wastewater, $18^{\text {th }}$ Ed. Washington, DC: Am. Public Health Assoc.

Babel, S.; Opiso E. M.; Removal of $\mathrm{Cr}$ from synthetic wastewater by sorption into volcanic ash soil. Int. J. Environ. Sci. Tech., 4 (1), 99-108 (10 pages).

Bitton, G., (2005). Wastewater microbiology, A John Wiley \& Sons Inc. Publication, $3^{\text {rd }}$ Ed., Hoboken, New Jersey Chap., 13, 345-369 (25 pages).

de Bok, F. A. M.; Plugge, C.; Stams, A. J. M., (2004). Interspecies electron transfer in methanogenic propionate degrading consortia. Water Res., 38, 1368-1375 (8 pages).

de Bok, F. A. M.; Harmsen, J. M.; Plugge, C. M.; de Vries, M. C.; Akkermans, A. D. L.; de Vos, W.M.; Stams, A. J. M., (2005). The first true obligatory syntrophic propionateoxidizing bacterium, Pelotomaculum schinkii sp. nov.; cocultured with Methanospirillum hungatei, and emended description of the genus Pelotomaculum. Int. J. Syst. Evol. Microbiol., 55, 1697-1703 (7 pages).

Gallert, C.; Winter, J., (2008). Propionic acid accumulation and degradation during restart of a fullscale anaerobic biowaste digester. Bioresource. Tech., 99, 170-178 (9 pages).

Gerardi, M. H., (2003). Wastewater microbiology series: The microbiology of anaerobic digesters. John Wiley and Sons Inc., New York.

Ghorbani, F.; Younesi, H.; Ghasempour, S. M.; zinatizadeh, A. A.; Amini. M.; Daneshi, A., (2008). Application of response surface methodology for optimization of cadmium biosorption in an aqueous solution by Saccharomyces cervisiae. Chem. Eng. J., 145, 267-275 (9 pages).

Han, S.K.; Kim, S.H.; Shin, H.S., (2005). UASB treatment of wastewater with VFA and alcohol generated during hydrogen fermentation of food waste. Proc. Biochem., 40, 28972905 (9 pages).

Hooshyari, B.; Azimi, A.; Mehrdadi, N., (2009). Kinetic analysis of enhanced biological phosphorus removal in a hybrid integrated fixed film activated sludge process. Int. J. Environ. Sci. Tech. 6 (1), 149-158 (10 Pages).

Hwang, M. H.; Jang, N. J.; Hyum, S. H.; Kim, I.S., (2004). Anaerobic bio-hydrogen production from ethanol fermentation: The role of pH. J. Biotech., 111, 297-309 (13 pages).

Kida, K.; Morimura, S.; Sonoda, Y., (1993). Accumulation of propionic acid during anaerobic treatment of distillery wastewater from barley-shochu making. J. Ferment. Bioeng., 75, 213-216 (4 pages)

Kim, I. S.; Hwang, M.H.; Jang, N.J.; Hyun, S.H.; Lee, S.T., (2004). Effect of low $\mathrm{pH}$ on the activity of hydrogen utilizing methanogen in bio-hydrogen process. Int. J. Hydrogen. Energ., 29, 1133-1140 (8 pages).

Kosaka, T.; Uchiyama, T.; Ishii, S.; Enoki, M.; Imachi, H.; Kamagata, Y.; Ohashi, A.; Harada, H.; Ikenaga, H.; Watanabe, K., (2006). Reconstruction and regulation of the central catabolic pathway in the thermophilic propionate-oxidizing syntroph Pelotomaculum thermopropionicum. J. Bacteriol., 188, 202-210 (9 pages).

Liu, R. R.; Tian, Q.; Yang, B.; Chen, J. H.; Hybrid anaerobic baffled reactor for treatment of desizing wastewater. Int. J. Environ. Sci. Tech., 7 (1), 111-118 (8 pages).

Mason, R. I.; Gunst, R. F.; Hess, J. L., (2003). Statistical design and analysis of experiments, with applications to engineering and science. $2^{\text {nd }}$ Ed. John Wiley \& Sons, New York.

Metcalf and Eddy Inc. (2004). Wastewater engineering: treatment and reuse., McGraw-Hill International Editions. $4^{\text {th }}$ Ed., New York, Chap. 10, 983-1035 (53 pages).

Montgomery, D.C., (1991). Design and analysis of experiments., John Wiley \& Sons, New York.

Myers, R.H.; Montgomery, D.C., (2002). Response surface methodology., $3^{\text {rd }}$ Ed., John Wiley \& Sons, New York.

Nwuche, C. O.; Ugoji E. O., (2008). Effects of heavy metal pollution on the soil microbial activity. Int. J. Environ. Sci. Tech., 5 (3), 409-414 (6 pages).

Nwuche, C. O.; Ugoji E. O., (2010). Effect of co-existing plant specie on soil microbial activity under heavy metal stress. Int. J. Environ. Sci. Tech., 7 (4), $697-704$ (8 pages). 
Plugge, C.; Balk, M.; Stams, A. J. M., (2002). Desulfotomaculum thermobenzoicum subsp. Thermosyntrphicum subsp. nov., a thermophilic, syntrophic, propionate-oxidizing, spore-forming bacterium. Int. J. Syst. Evol. Microbiol., 52, 391-399 (9 pages).

Pullammanappallil, P.C.; Chynoweth, D.P.; Lyberatos, G.; Svoronos, S.A., (2001). Stable performance of anaerobic digestion in the presence of a high concentration of propionic acid. Bioresource. Tech., 78, 165-169 (5 pages).

Schink, B.; Stams, A.J.M., (2005). Syntrophism among prokaryotes. In: Dworkin M. (Ed.), The prokaryotes: an evolving electronic resource for the microbiological community, $3^{\text {rd }}$ Ed. Springer, New York.

Schmidt, J. E.; Ahring, B. K., (1995). Interspecies electron transfer during propionate and butyrate degradation in mesophilic, granular sludge. Appl. Environ. Microbiol., 61 (7), 2765-2767 (3 pages).

Shah, B. A.; Shah, A. V.; Singh, R. R. (2009). Sorption isotherms and kinetics of chromium uptake from wastewater using natural sorbent material. Int. J. Environ. Sci. Tech., 6 (1), 77-90 (14 Pages).

Siegert, I.; Banks, C., (2005). The effect of volatile fatty acid addition on the anaerobic digestion of cellulose and glucose in batch reactors. Process. Biochem., 40, 3412-3418 (7 pages)

Söteman, S. W.; Ristow, N. E.; Wentzel, M. C.; Ehama, G. A., (2005). A steady state model for anaerobic digestion of sewage sludge. Water South Africa, 31 (4), 511-527 (17 pages).

Tatara, M.; Makiuchi, T.; Ueno, Y.; Goto, M.; Sode, K., (2008). Methanogenesis from acetate and propionate by thermophilic down-flow anaerobic packed-bed reactor. Bioresource Tech., 99, 4786-4795 (10 pages).

Turovskiy, I. S.; Mathai, P. K., (2006). Wastewater sludge processing. New York: Wiley.

Uneo, Y.; Tatara, M., (2008). Microbial population in a thermophilic packed-bed reactor for methanogenesis from volatile fatty acids. Enzyme Microbiol. Tech., 43, 302308 (7 pages).

Wang, G.; Mu, Y.; Yu, H.Q., (2005). Response surface analysis to evaluate the influence of $\mathrm{pH}$, temperature and substrate concentration on the acidogenesis of sucrose-rich wastewater. Biochem. Eng. J., 23, 175-184 (10 pages).

Wong, B. T.; Show, K. Y.; Lee, D.J.; Lai, J. Y., (2009). Carbon balance of anaerobic process: Carbon credit. Bioresource. Tech., 100, 1734-1739 (6 pages).

Zinatizadeh, A. A. L.; Mohamed, A. R.; Abdullah, A. Z.; Mashitah, M.D.; Hasnain Isa, M.; Najafpour, G. D., (2006). Process modeling and analysis of palm oil mill effluent treatment in an up-flow anaerobic sludge fixed film bioreactor using response surface methodology (RSM). Water Res., 40, 3193-3208 (16 pages).

\section{AUTHOR (S) BIOSKETCHES}

Amani, T., Ph.D., scholar, Biotechnology Group, Department of Chemical Engineering, Tarbiat Modares University, P.O. Box 14115143, Tehran, Iran. Email: tamani@modares.ac.ir

Nosrati, M., Ph.D., Assistant Professor, Biotechnology Group,Department of Chemical Engineering, Tarbiat Modares University, P.O. Box 14115-143, Tehran. E-mail: mnosrati20@modares.ac.ir

Mousavi, S.M., Ph.D., Assistant Professor, Biotechnology Group,Department of Chemical Engineering, Tarbiat Modares University, P.O. Box 14115-143, Tehran, Iran. E-mail: mousavi_m@modares.ac.ir

Kermanshahi, R.K., Ph.D., Full Professor, Department of Biology, Faculty of Basic Sciences, Alzahra University, Tehran, Iran. E-mail: rkasra@yahoo.com

How to cite this article: (Harvard style)

Amani, T.; Nosrati, M.; Mousavi, S. M.; Kermanshahi, R. K., (2011). Study of syntrophic anaerobic digestion of volatile fatty acids using enriched cultures at mesophilic conditions. Int. J. Environ. Sci. Tech., 8 (1), 83-96. 